Print ISSN: 2288-4637 / Online ISSN 2288-4645

doi:10.13106/jafeb.2020.vol7.no10.423

\title{
Developing Strategy for Heritage Tourism Supply Chain Quality Management
}

\author{
Yeni SUMANTRI ${ }^{1}$
}

Received: July 18, 2020 Revised: August 23, 2020 Accepted: September 03, 2020

\begin{abstract}
Increasing the tourism sector has a positive impact on a country. The Indonesian government has targeted to increase the number of tourists from year to year including the heritage tourism sector. However, the number of the heritage tourism sector increases slowly. To overcome this problem, this research is aimed to investigate the services performed by managements of that sector; the barrier and driver factors of heritage tourism supply chain quality management; and to identify strategies that can be implemented to improve the sector. This study used SERVQUAL method to analyze service performance of the sector. Furthermore, an in-depth interview was conducted to achieve completed objectives. The data obtained from questionnaires and interviews in several heritage tourism areas located in East Java Province of Indonesia. The results show that all SERVQUAL dimensions stay on the adequate value range. Visitors argue that the heritage tourism sector in East Java has interesting locations, collections and circumstances. However, the sector has several weaknesses compared to other tourism sectors. The strategy that can be done to improve the performance of this sector are to perform the area as an event venue, additional visiting hours, integration with other types of tourism sectors, making websites as a means of promotion.
\end{abstract}

Keywords: Heritage Tourism Sector, Supply Chain, Quality Management, Strategy

JEL Classification Code: L15, L80, L90, M30, O25

\section{Introduction}

Tourism sector in Indonesia is one of the most developed industry segments. The improvement of the sector is supported by adequate infrastructure, qualified human resources, as well as intensive and well-planned marketing activities. The increase of tourist arrivals has had a positive economic impact on Indonesia (Chamidah, Guntoro, \& Sulastri, 2020; Purnomo, Rahayu, Riani, Suminah, \& Udin, 2020). One of the tourism sectors in Indonesia is heritage tourism. Heritage tourism can be instrumental in increasing the understanding of national culture.

Heritage tourism includes various activities such as seeing art performances, seeing cultural festivals, visiting

${ }^{1}$ First Author and Corresponding Author. Lecturer, Department of Industrial Engineering, Faculty of Engineering, Universitas Brawijaya, Indonesia [Postal Address: JL. MT Haryono 167 Malang, Jawa Timur, 65145, Indonesia] Email: yeni@ub.ac.id

(c) Copyright: The Author(s)

This is an Open Access article distributed under the terms of the Creative Commons Attribution Non-Commercial License (https://creativecommons.org/licenses/by-nc/4.0/) which permits unrestricted non-commercial use, distribution, and reproduction in any medium, provided the original work is properly cited. traditional settlements, visiting cultural heritage sites and visiting museums. Heritage tourism must be able to overcome the challenges of the tourism sector in the modern era. One of them is how heritage tourism can be a source of entertainment as well as edutainment (Alcaraz, Hume, \& Mort, 2009; Cunnell \& Prentice, 2000; Gilmore \& Rentschler, 2002). For this reason, the management should perform various efforts to overcome these challenges.

Lack of information about heritage tourism results in the community having no desire to visit heritage locations. The more interesting of other tourism types conduce declining community interest to do heritage tourism. Most heritage tourism is carried out independently by the management through the entrance ticket. The lack of visitors causes less operating funds so as the maintenance of the collection is not optimal (Giao, Hang, Son, Kiem, \& Vuong, 2020).

On the other hand, in some literature on tourism research, it was found that management holds an important role in increasing the frequency of tourist visits. They should perform great efforts to achieve the goal. However, several literature show that these findings cannot be generalized to all tourism locations, so for other locations more in-depth research needs to be done. Several previous studies used 
service quality dimensions which are used generally in other sectors (Lin, Wu, \& Ling, 2017; Titu, Raulea, \& Titu, 2016). In this research, some service quality dimensions were adjusted to the condition in the place studied.

This condition requires an analysis of the problem root of decreasing heritage tourism in terms of tourism supply chain quality management, namely by analyzing the quality of service from upstream to downstream from the point of view of all stakeholders, from the management to visitors. This is useful to identify the service failures based on visitor experience and identify obstacles encountered by the management during the service delivery process.

Based on the previous background, this research is directed to analyze 1) barrier and driver factors in the heritage tourism sector; 2) strategies that can be implemented to improve heritage tourism so that the sector can be sustainable in point of view tourism supply chain quality management. The next section will explain the theoretical framework and research methodology of this study. At the end, a discussion of the study findings and conclusions are presented.

\section{Literature Review}

\subsection{Definition and Types of Tourism}

Tourism is a temporary trip from one place to another that is carried out by individuals or groups in order to find balance, harmony and happiness within the social, cultural, natural and scientific dimensions of the environment (Hunter \& Gerber, 2010). Several factors that attract tourists includes reasonable price; convenience during tourism activities; reputation of the tourism area; natural and cultural appeal; and the friendliness of the community.

Tourism can be divided into several types, namely pleasure tourism; recreation tourism; cultural or heritage tourism; business tourism; sports tourism; and convention tourism. Pleasure tourism is tourism to enjoy the beauty of nature while recreation tourism is the holiday to rest and refresh physical and spiritual condition. Heritage tourism is marked by learning activities at the research center, visiting historical monuments, visiting and studying ancient relics and music festivals. Business tourism is usually done by entrepreneurs by conducting business visits. Sports tourism is carried out for sporting purposes such as the Olympic Games or practicing a sport, such as climbing, hunting or other sports. Convention tourism relates to the conferences or symposiums.

\subsection{The Role of Heritage Tourism}

At the beginning of the development of the heritage tourism sector, the main role of the sector was to collect and conserve valuable objects and educate visitors about the objects. Currently, the sector has shifted the focus area, from being a goods collector to a service delivery. Heritage tourism management is not only as a collector of valuable objects collections but also as a provider to educate and entertain the community. Because of this shifting, the sector has become economically more beneficial and subsequently results in accountability and marketability of a city (Alcaraz et al., 2009).

At the beginning of the development of the heritage tourism sector, most of these sectors were non-profit organizations. Some of these sectors are funded by the government and others are funded by private companies, investors and sponsors. Although most of them were nonprofit organizations in the beginning, now the role of the sector has become a source of income for stakeholders. Heritage tourism has become one of the new business fields. The sector has been more competitive and independent (Goulding, 2000). The heritage tourism sector should improve governance and overcome weaknesses of its services.

\subsection{Business Sustainability from the Heritage Tourism Sector}

In general, some of the weaknesses of the heritage tourism sector management are lack of customer orientation, lack of customer interaction and less able to present their collection in an interesting way (Boorsma, 2006). These weaknesses make the business sector less sustainable (Purnomo et al., 2020). Sustainability means the sector has sufficient resources to maintain existence and meet longterm goals (Weerawardena \& Mort, 2006). Sustainability in the business is needed because of the high competition in the tourism sector. Increased competition among the tourism sector lead to the heritage tourism sector needing to improve the services quality to achieve visitor satisfaction (Harrison $\&$ Shaw, 2004). The service quality in the tourism sector can increase the visiting of tourists and purchasing souvenir products (Babakus, Bienstock, \& Scotter, 2004; RamsaranFowdar, 2007).

For the sustainability of the heritage tourism sector, the sector must provide value for stakeholders by attracting many visitors (Gilmore \& Rentschler, 2002). Heritage tourism managers must present to investors and sponsors that they are eligible to be funded by proving that they have a high number of visitors. One of the most serious challenges facing this sector in the 21st century is how to increase the number of visitors and increase their satisfaction at the same time. The level of visitor satisfaction determines the number of subsequent visits (Rojas \& Camarero, 2008). For sustainability of the heritage tourism sectors, managers need to focus on presenting contemporary and relevant services to visitors. Services that can meet the expectations of visitors 
provide value to visitors directly and to investors indirectly. In order for the heritage tourism sector provide value to visitors and investors, management must focus on the primacy of the offered service design functions. Understanding the dimensions of customer service is very important to increase customer visits and create value for visitors and investors (Sumantri, 2019, 2020). The management of heritage tourism has evolved from a traditional perspective to a service marketing perspective (Johanson \& Olsen, 2010). The adoption of a service-centric approach is one way to manage the sustainable heritage tourism sector.

\subsection{Tourism Supply Chain Quality Management as a Multi Point of View for Assessment}

In the service-centric approach, the role of visitor feedback is very important. The role of visitors not only serves as a means of collecting income but also as creating market value for investors and sponsors. The relationship between customers, income and value creation, both socially and monetarily, must be understood by managers of heritage tourism. By improving the quality of service, the sector can increase visitors and revenue (Goulding, 2000). A way to adopt a service-center approach is to analyze the feedback from visitors regarding their visit experiences.

Nowadays, visitor experience is important (Cunnell \& Prentice, 2000). Visitor experience is a subjective mental condition felt by visitors during service. Visitor experience is mainly influenced by the management of tourist attractions, facilities owned, and the media used for promotion (Falk \& Dierking, 2013; Kirchberg \& Trondle, 2012). In general, visitor experience is determined by the quality of services provided by the manager. The quality of this service will affect visitor satisfaction. Therefore, the manager must always evaluate the services that they provide.

Quality of service for the service sector is difficult to evaluate because its service nature is intangible and heterogeneous (Parasuraman, Zeithaml, \& Berry, 1988). The quality of service provided is shaped by the perception of visitors compared to the expectations that they have. Visitor heterogeneity makes visitor experiences evaluation complicated. Visitors of the heritage tourism sector consist of people who have varied interests. Their experiences and life knowledge are different and affect their perception about the services provided (Forrest, 2013). By considering the interests of visitors are very diverse, the manager of heritage tourism must be competent in shaping the visitor's experience properly and removing the arising obstacles in the service process.

To assess service quality, managers of the heritage tourism sector also must evaluate visitor dissatisfaction caused by service failures. Information about factors triggering visitor dissatisfaction is useful to analyze inadequate services and create opportunities for improvement. Service failure can be defined as service performance that falls below customer expectations (Sparks \& Browning, 2010). Service failures can occur during the service delivery process (Lewis \& McCann, 2004). Service failures result in customer complaints, customer dissatisfaction and customer defection (Mattila, 2001). Information about customer complaints is very important to improve service quality (SanchezGarcia \& Curras-Perez, 2011; Sparks \& Browning, 2010). Identification of the source of service failure obtained from visitor complaints is needed to shape the future service design.

Some respondents suggested that the management of heritage tourism should increase the supporting factors of visitor satisfaction and reduce the disappointing factors. The following are some aspects increasing customer satisfaction within heritage tourism services (Alcaraz et al., 2009), namely 1) excitement; 2) entertainment; 3 ) education culture; 4) interactivity and display updates; 5) minimize waiting time and queues; 6) frontline personnel behavior.

The intention of visitors to subsequent visits is also influenced by dissatisfied aspects. In some heritage tourism locations, the visitor surge has an impact on tourism operations, generating long waiting lines, noise, discomfort and disruption among visitors. Complaints from visitors are the key to understand visitor dissatisfaction. Extraction of these findings is useful for identifying failure of heritage tourism services from the viewpoint of visitors. Following are the quality of services that must be improved in heritage tourism sector (Su \& Teng, 2018), specifically

\section{Convenience quality}

The most frequent service failures are related to long waiting lines. This situation results in decreasing convenience quality. To overcome this problem, the convenience quality can be improved through an online ticket service and parking area expansion.

\section{Contemplation quality}

The second dissatisfaction relates to contemplation quality. The lack of contemplation quality stems from the density of visitor number. This condition causes the inconvenience of the tourism area environment and does not support visitors to understand the displayed collection. Heritage tourism services are more on the process of presenting visual perceptions of creation (Tzortzi, 2016) so that if the number of visitors is excessive then the contemplation process of visitors becomes difficult.

\section{Assurance quality}

The third most common complaint is related to assurance quality. The disappointment source from discrepancy between the expectations of visitors with the collection of heritage items. A collection owned by a heritage tourism must reflect and strengthen the theme of exhibited content. The manager of heritage tourism must ensure that visitors 
are physically, intellectually and emotionally satisfied with the provided services.

\section{Responsiveness \& Empathy quality}

The fourth dissatisfaction comes from the lack of responsiveness and empathy quality. The dimension of responsiveness \& empathy quality is defined as the willingness of staff to help and empathize customer difficulties and provide fast service. Tourist complaints about staff stem from a lack of response to visitor complaints and insufficient staff number. Staff attention given to disabled visitors needs to be increased.

\section{Reliability quality}

The fifth visitor dissatisfaction comes from the lack of reliability quality. The dimension of reliability quality is defined as the ability of management to deliver the promised service reliably and accurately. The unexpected closure of the heritage tourism location has disrupted the visitor's schedule and the manager's commitment to the public.

\section{Communication facility quality}

Wi-Fi services must be upgraded to accommodate communication (Chamidah et al., 2020). Multi-language services must also be improved. Multilingual services are the basic elements that must be provided such as signage and labeling of collections. Multilingual services can provide a more memorable experience (Alcaraz et al., 2009).

\section{Servicescape quality}

Servicescape quality refers to the physical environment in which the service delivery process takes place (Bitner, 1992). Servicescape emphasizes the holistic impact of the physical environment. The servicescape framework consists of three groups of physical proof factors, namely ambient conditions (air quality, temperature, noise, etc.); spatial and functionality (building layout and equipment arrangement); use of signs and symbols.

\section{Consumable services quality}

The shops and cafes at the heritage tourism location not only act as retail businesses located on site for the purpose of generating income but also provide public services that shape the visitor experience of heritage tourism (Theobald, 2000). Complaints about the consumable service quality are mostly related to the quality and price of food.

\section{Purposive quality}

At the beginning, the development of a heritage tourism area was a non-profit institution serving the community and aimed to provide preservation and research. Referring to the definition, complaints will occur if visitors feel that a heritage tourism sector is too commercialized. The key to ensuring the quality and success of a heritage tourism is the compatibility between the activities carried out and the mission or the mandate given to the heritage tourism (Weil, 2002). Currently, visitors argue that the role of heritage tourism shifts from non-profit organizations to more incomeoriented one.

\section{Research Methods and Materials}

\subsection{Research Design}

This study explores the evaluation of visitors to service quality of heritage tourism sectors and factors influencing consumer visits to the heritage tourism area, which are driver and barrier factors influencing the community to conduct heritage tourism. The obtained findings are used to formulate strategies and improve the heritage tourism sector. This study used cross-sectional study. This section discusses the development of methods that involves identification of the research design; selection of dimensions and attributes; designing and testing of questionnaires; and sampling, data collection and analysis design.

The study was conducted in East Java Province of Indonesia. As there is little information and study about service quality in the heritage tourism sector in East Java Province, a wide-ranging search of literature all over the other sector is performed and opinion of experts are collected to design this study. Data was obtained through questionnaires and interviews. Based on the expert opinion and extensive literature review, the questionnaire and interview attributes were designed in this research.

\subsection{SERVQUAL Model}

SERVQUAL is the combination of 'Service' and 'Quality'. It is an obtrusive tool. It can be used to evaluate the quality of services delivered by the organizations by diagnosing quality dimensions. The SERVQUAL model has five dimensions for evaluating the quality of services. It was developed by Parasuraman et al. (1988) and is an instrument for measuring service quality, represented by five dimensions, namely 1) reliability, 2) responsiveness, 3) assurance, 4) empathy, and 5) tangible.

Reliability is related to the reliability of this sector in providing services for visitors such as qualified communication facilities. It refers to the capability to deliver service accurately and dependably in a certain manner. Responsiveness indicates the willingness of management to help consumers and perform service within minimum time. It refers to the ability to recognize customer needs. Assurance is related to guarantee of employee behavior in fostering consumer confidence. It includes knowledge, competency, credibility, courtesy and ability of employees to inspire confidence and trust of the customers. Empathy means understanding and caring for the customer and delivering the individualized attention to customers. It refers to the awareness of employees to empathize with customer needs including children and disability people. Tangible deals with the attendance of equipment, physical facilities, and personnel of services. It refers to property environments, 
such as cleanliness, additional services in the form of restaurants and shops.

\subsection{Questionnaire Design}

This study aims to assess the customer evaluation on heritage tourism service quality in East Java based on SERVQUAL and interview the visitors and management on the enabler and barrier of this sector. The questionnaire used refers to the service dimension in SERVQUAL. The SERVQUAL questionnaire involves 25 questions related to service quality under five dimensions i.e., Reliability (5 questions), Responsiveness (5 questions), Assurance (5 questions); Empathy (5 questions) and Tangibility (5 questions). The questions of dimensions are selected based on expert interview and comprehensive literature review. The questionnaire is developed both in Indonesian version for the better consideration of experts and respondents. The questionnaire items are rated on 5-point Likert scales in a structured format.

In a survey-based research, the measurement of validity and reliability of the questionnaire is critical to control whether the questions cover the problem or issues being measured. In order to measure the validity of the 25 questionnaire items, this study used the content validity index. In the advance of content validity index, a panel of experts requested to review the questions on a three-point Likert scale that 1 refers to not relevant and 3 indicates relevant. By using SPSS software, the opinion of five experts are analyzed to quantify the validity of 25 questionnaire items. The result of the content validity index is 0,81 that is a good content validity. Cronbach's alpha method is used to measure the reliability of the questionnaire items. Based on a pilot questionnaire survey, Cronbach's alpha is found to be 0,75 . It can be concluded as a good sign for reliability of the questionnaire.

\subsection{Sampling, Data Collection and Analysis Design}

A simple random sampling approach was employed in this study. The research assistants approached the selected participants in all heritage tourism locations in East Java to deliver questionnaires and perform interviews. The questionnaire used has passed a series of tests before being distributed to visitors, such as reliability and validity tests. The scale used is a Likert scale from 1 to 5, each representing conditions from very poor to very good. Questionnaires were taken from 150 respondents. The research sample was taken from visitors in the heritage tourism area in East Java of Indonesia, which is one of the quite large provinces in Indonesia and has quite a lot of industrial sectors.

The questionnaire consists of two parts. Part 1 consists of 25 questions which is aimed at acquiring the respondents' valuations of service quality. The answers of respondents to the questions were recorded on a 5-point scale. Part 2 is focused on questioning demographic data about place of origin, age, gender, profession, and times travelled per year. Before collecting the real survey, a pilot test was conducted. Based on the response from a pilot test, it was found that the logic of the survey was good. However, there were several answers of questions found to be missing. The most important change was performed. To repair this problem, the attribute was removed. At the end, this study only used 15 questions in part 1 of the survey as can be seen in Table 1 . The final questionnaire was sent to 150 potential respondents. After preliminary cleaning of the responses, this study can achieve 100 completed questionnaires.

After the service quality data from the questionnaire is obtained, the next step is to conduct in-depth interviews to explore factors that encourage and discourage consumers to conduct heritage tourism. The factors are needed to improve service quality, customer satisfaction and customer desire to further visit. The interviews are guided by open-ended questions that focus on the desired service process. The results of the interviews were conducted to a content analysis process to extract the causes of success and failure of the services based on feedback from visitors and managers.

The relevant information was summarized from the result of an in-depth interview. There were fifty interviews carried out. Each of the interviews used time between 15 min to 30 min. The responses delivered by respondents were noted and analyzed. Content analysis methods were performed in this study. Content analysis was performed in a stage-by-stage manner starting from segregating to classifying of categories of the interview results. The results were compared with the research framework from literature review. Results that did not fit with the research framework then were noted and close attention was paid to those results during the analysis of the whole data. If there was a critical attention from the respondents for certain questions, then the focus of respondents was added to the results as new findings in the research model. Finally, at the end of content analysis, the robust results can be achieved.

The survey data were analyzed using the SPSS. Descriptive analysis such as mean and standard deviation were performed. Inferential statistics such as samples t-test were conducted also to examine service quality perceptions. From highlighting perceptions, the samples t-test also helped identify significant service quality items and dimensions.

\section{Results and Discussion}

The following will be displayed measurement results through a questionnaire, which consists of the dimensions of reliability, responsiveness, assurance, empathy and tangible. 
Table 1: The Dimension for Evaluating the Quality of Service in Heritage Tourism Sector

\begin{tabular}{|l|l|}
\hline Dimensions & \multicolumn{1}{|c|}{ Questionnaire item } \\
\hline Reliability & The quality of the collection \\
\hline & The price of entrance \\
\hline Responsiveness & The information provided to facilitate visitors in observing the collection displayed \\
\hline & The alertness of employees to respond all visitor complaints \\
\hline & The alertness of employees to explain the rules of the visit \\
\hline Assurance & The alertness of employees to provide information about the collection \\
\hline & The guarantee of the provided information for visitor about the collection \\
\hline Empathy & The security guarantee for visitors \\
\hline & The guarantee of ticket returns if there are customer complaints \\
\hline & The friendliness of officers in providing services \\
\hline Tangible & The fairness in attitude of officers when serving visitors \\
\hline & The enough time given by officers in providing services \\
\hline & The strategic location of the heritage tourism area \\
\hline & The properly supporting facilities \\
\hline & The interior design and the arrangement of the collection \\
\hline
\end{tabular}

\subsection{Reliability}

The reliability dimension is related to reliability in providing services to visitors. The dimensions of the evaluation parameters are related to 1) the quality of the collection; 2) the price of entrance; and 3) the information provided to facilitate visitors in observing the collection displayed. Overall, the reliability dimension for cultural heritage tourism in this case study is within the adequate value range. Clarity of information about the collection has the highest value compared to the other two indicators. The next higher value is regarding the price of entrance. The lowest value on the reliability dimension is the indicator of the caring quality of the collection items.

\subsection{Responsiveness}

The responsiveness dimension is related to the ability to recognize and respond to customer needs. Indicators of responsiveness dimensions include 1) the alertness of employees respond to all visitor complaints; 2) the alertness of employees explain the rules of the visit; 3) the alertness of employees provide information about a collection. The responsiveness dimension for cultural heritage tourism in this case study is within the adequate value range. From the results of the questionnaire, the readiness of employees to respond to all visitor complaints has the highest value compared to the other two indicators. The next higher value is regarding the awareness of employees to always explain the rules of the visit to visitors. The lowest value is the indicator of the alertness of employees to provide information about a collection.

\subsection{Assurance}

The assurance dimension is related to guarantees of employee behavior and growing customer confidence in the services provided. The assurance dimension is related to the guarantee of the provided information for visitors about the collection is valid. This dimension measures the security guarantee for visitors and also guarantees ticket returns if there are customer complaints. The assurance dimension for cultural heritage tourism in this case study is within the adequate value range. From the results of the questionnaire, the guaranteed return of tickets if there are complaints from customers has the highest value compared to the other two indicators. The next higher value is the safety guarantee for visitors and the lowest value in the assurance dimension is the validity of provided information by employees to visitors about the collection.

\subsection{Empathy}

The empathy dimension is related to the attention of officers to the needs of visitors. In this study, empathy dimension related to 1) the friendliness of officers in 
providing services; 2 ) the fairness attitude of officers when serving visitors; 3 ) the enough time given by officers in providing services. The empathy dimension for cultural heritage tourism in this case study is within the adequate value range. From the results of the questionnaire, the friendliness of the officers when giving information to visitors has the greatest value compared to the other two indicators. The next higher value is the fairness attitude of officers when serving visitors and the lowest value in the empathy dimension is the indicator of the adequacy of time given by officers in providing services to visitors.

\subsection{Tangible}

Tangible dimensions are related to the attractiveness of physical facilities such as facilities and infrastructure used in the heritage tourism area. Tangible dimension related to location, interior design and collection arrangement as well as supporting facilities provided by the manager. The tangible dimension for cultural heritage tourism in this case study is within the adequate value range. The strategic location of most heritage tourism areas has the greatest value compared to the other two indicators. The next higher value is an indicator of properly supporting facilities. The lowest value on tangible dimensions is the interior design and the arrangement of the collection. The result of questionnaire analysis can be seen in the following figure.

After analyzing the results of the questionnaire, an indepth interview was conducted with several visitors to verify the results of the questionnaire. Data obtained from interviews are as follows. Visitors agree that heritage tourism is quite interesting compared to other tourism types. However, tourism has many shortcomings compared to other tourism types. The weaknesses that must be corrected from the results of the interview are the same with the information obtained from the questionnaire, namely 1) collection of goods that are poorly maintained; 2) officers are not quick in providing information; 3 ) the validity of the information provided by the officers is doubt; 4) the service time provided by the officers is lacking; 5) interior and exterior design and collection arrangement are not well arranged; 6) lack of technological touches such as the animation room; 7) lack of promotion facilities that can reach a wider area, such as a website; 8) the information provided is not multilingual. Besides some weaknesses, heritage tourism in this study has several strengths, including 1) easily accessible locations; 2) the completeness and authenticity of the collection; 3) availability of supporting facilities; 4) good circumstances and not noisy; 5) affordable entrance rates.

Some weaknesses and strengths of heritage tourism are then discussed with several relevant stakeholders from facilities and infrastructure suppliers, policy making, and managers. From the results of the interview, it can be identified as follows. There are some difficulties to overcome the weaknesses, including 1) difficulties in collaborating with stakeholders and 2) the other tourism types in this case study are more interesting for visitors and easier to develop.

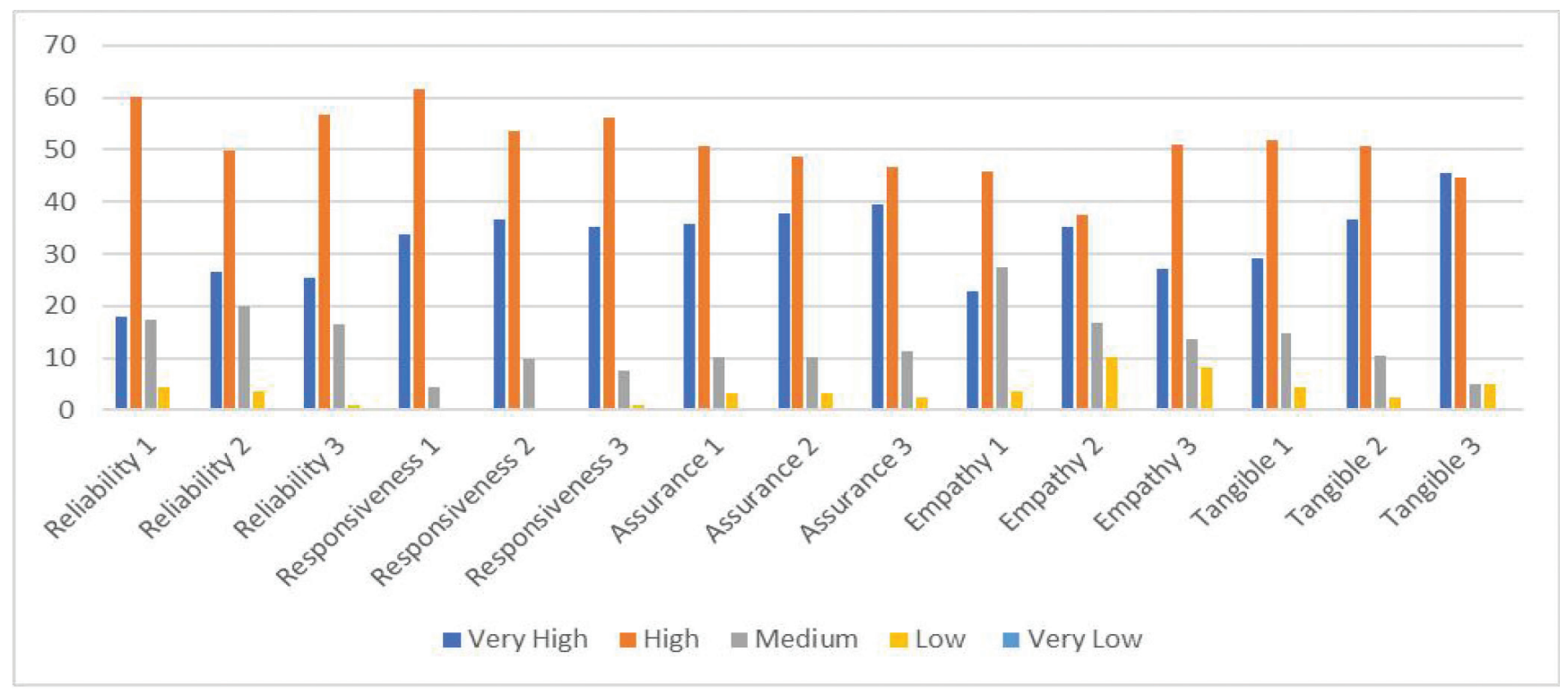

Figure 1: The Customer Point of View to Services Quality of Heritage Tourism (Percent) 
Based on information obtained through both questionnaires and interviews, the following are strategies that can be used to develop heritage tourism in this case study, i.e.

(1) Integrating heritage tourism with other types of tourism.

(2) Optimizing promotional facilities

(3) Establishing the heritage tourism location an event venue or meeting place

(4) Performing an official website for heritage tourism

(5) Developing other facilities that are not optimal yet to provide comfort, such as a) facilities at the queue line; b) facilities at the location of collection; c) communication facilities

(6) Performing multi-language services

(7) Realizing periodic maintenance of collections owned

(8) Increasing responsiveness, empathy and knowledge of officers

(9) Improving the physical environment, such as location conditions, spatial planning, use of signs or symbols

(10) Adding supporting facilities such as shops and cafes with quality food affordable.

The results of this study are in line with studies that have been carried out in Romania and China (Lin et al., 2017; Titu et al., 2016). The development of the tourism sector has triggered the higher competition among tour operators as a result of globalization and deregulation. The invention in information technology accelerates the emergence of a knowledge-based economy driven by innovation. The increasing role of the tourism sector and competition in this sector encourages the importance of developing quality tourism services. To develop quality tourism, managers need to know the competitive advantages that can be offered so that the tourism sector can continue to grow.

\subsection{Implications for Theory and Management}

The service shortages identified in this study are aspects that must be corrected by heritage tourism management in East Java of Indonesia. Adopting a service paradigm in the management of heritage tourism will be useful and helpful in providing services to consumers. Heritage tourism management must be customer oriented and provide the expected services. Understanding the needs of market segments will offer a more valuable and enjoyable experience for customers. The service strategy must involve interactivity aspects with visitors, the use of technology to improve edutainment, the addition of entertainment aspects, the provision of comfortable space and the increasing role of frontline staff. The addition of services that distinguish heritage tourism from competitors can improve the quality and value felt by visitors (Gronroos, Heinonen, Isoniemi, \& Lindholm, 2000). Additional services provided by the manager will enhance the holistic experience and satisfaction of visitors (Giao et al., 2020). The marketing-oriented heritage tourism sector must seek extra services needed by visitors.

Considering that the main role of heritage tourism is for conservation and education, sharing and stimulating knowledge should be the focus of heritage tourism services. Relationship marketing strategy is important for management improvement. The strategy shifts the custodial centric paradigm into the service paradigm (Gilmore \& Rentschler, 2002). Related to the implementation of this strategy, several additional services can be used to increase visitors, such as sharing knowledge, providing cafes and other services. Heritage tourism must proactively offer maps, directions, online bookings, activity sheets for children, online games, and various other services.

This research can be developed not only for heritage tourism supply chain but also for other types of tourism supply chain. Related to the variables used, it can also be adjusted to the condition of the tourism sector studied and the data collection techniques used. Associated with the development of methods, it can be used in other methods, such as the KANO model, in depth interview or mix method.

\section{Conclusions}

Overall, this study analyzes the experience of heritage tourism visitors to identify factors that will increase customer expectations and satisfaction and then will affect the sustainability of heritage tourism. Visitors have expected heritage tourism as a source to add insight, experience, education and entertainment. Consumers interviewed provided invaluable feedback to increase the number of visits. This study also identified the failure of heritage tourism services in East Java of Indonesia. Initially, the mission carried out by heritage tourism was as a means of curatorial artifacts and focused on aspects of education. At present, there has been a shift in mission of heritage tourism, from curatorial artifacts becoming a means of entertainment. The change of mission resulted in the change of service quality provided. The service provided must adjust to visitor expectations. Visitor dissatisfaction affects the visitor's assessment of the service. This information can be used to identify the service aspects that must be improved.

The dominant influential factors of supply chain quality management of heritage tourism are information clarity; the responsiveness of the officer to overcome any complaints from visitors; the courtesy of the officer when serving visitors; the friendliness of the officer when giving information to visitors; and the proper facilities. Supply chain quality management in heritage tourism in East Java of Indonesia has 
several strengths such as strategic location, completeness and authenticity of collections, cheap ticket prices, large parking area, availability of public facilities, and a safe and not noisy atmosphere. As for the weaknesses are inadequate quantity and quality of tour guides, lack of protective collections, low service technology, absence of animation and conservation space, damaged and dirty objects, low collaboration among stakeholders. The strategy that can be done to improve the performance of this sector are integrating heritage tourism with other types of tourism; optimizing promotional facilities; establishing the heritage tourism location an event venue or meeting place; performing an official website for heritage tourism; developing communication facilities; performing multi-language services; realizing periodic maintenance of collections owned; increasing responsiveness, empathy and knowledge of officers; improving the physical environment; and adding supporting facilities such as shops and cafes with quality food affordable. For further research, it will be valuable to identify supply chains of tourism sector from the other perspective, such as safety service for visitors in the disease disaster such as the impact of COVID-19 pandemic on the tourism sector.

\section{References}

Alcaraz, C., Hume, M., \& Mort, G. S. (2009). Creating sustainable practice in a museum context: Adopting service-centricity in nonprofit museums. Australasian Marketing Journal, 17(4), 219-225.

Babakus, E., Bienstock, C. C., \& Scotter, J. R. Van. (2004). Linking perceived quality and customer satisfaction to store traffic and revenue growth. Decision Sciences, 35(4), 713-737.

Bitner, M. J. (1992). Servicescapes: The impact of physical surroundings on customers and employees. Journal of Marketing, 56(2), 57-71.

Boorsma, M. (2006). A strategic logic for arts marketing. International Journal of Cultural Policy, 12(1), 73-92.

Chamidah, N., Guntoro, B., \& Sulastri, E. (2020). Marketing communication and synergy of pentahelix strategy on satisfaction and sustainable tourism. Journal of Asian Finance, Economics and Business, 7(3), 177-190. https://doi. org/10.13106/jafeb.2020.vol7.no3.177

Cunnell, D., \& Prentice, R. (2000). Tourist's recollections of quality in museums: A service space without people? Museum Management and Curatorship, 18(4), 369-390.

Falk, J. H., \& Dierking, L. (2013). The museum experience revisited. Walnut Creek, CA: Left Coast Press.

Forrest, R. (2013). Museum atmospherics: The role of the exhibition environment in the visitor experience. Visitor Studies, 16(2), 201-216.

Giao, H. N. K., Hang, T. D., Son, L. T., Kiem, D., \& Vuong, B. N. (2020). Tourists' satisfaction towards Bao Loc City, Vietnam.
Journal of Asian Finance, Economics and Business, 7(7), 269-277. https://doi.org/10.13106/jafeb.2020.vol7.no7.269

Gilmore, A., \& Rentschler, R. (2002). Changes in museum management: a custodial or marketing emphasis? Journal of Management Development, 21(10), 745-760.

Goulding, C. (2000). The museum environment and the visitor experience. European Journal of Marketing, 34(3/4), 261-278.

Gronroos, C., Heinonen, F., Isoniemi, K., \& Lindholm, M. (2000). The Net Offer model: A case example from the virtual marketspace. Management Decision, 38(4), 243-252.

Harrison, P., \& Shaw, R. (2004). Consumer satisfaction and post-purchase intention: An exploratory study of museum visitors. International Journal of Arts Management, 6(2), 23-32.

Hunter, J., \& Gerber, A. (2010). Harvesting community annotations on 3D models of museum artefacts to enhance knowledge, discovery and reuse. Journal of Cultural Heritage, 11, 81-90.

Johanson, L. B., \& Olsen, K. (2010). Alta museum as a tourist attraction: The importance of location. Journal of Heritage Tourism, 5(1), 1-16.

Kirchberg, V., \& Trondle, M. (2012). Experiencing exhibitions: A review of studies on visitor experiences in museums. Curator: The Museum Journal, 55(4), 435-452.

Lewis, B. R., \& McCann, P. (2004). Service failure and recovery evidence from the hotel industry. International Journal of Contemporary Hospitality Management, 16(1), 6-17.

Lin, M., Wu, X., \& Ling, Q. (2017). Assessing the effectiveness of empowerment on service quality: A multi-level study of Chinese tourism firms. Tourism Management, 61(August), 411-425.

Mattila, A. (2001). The impact of product category risk on service satisfaction evaluations. International Journal of Hospitality Management, 20(1), 29-43.

Parasuraman, A., Zeithaml, V. A., \& Berry, L. L. (1988). SERVQUAL: A multiple-item scale for measuring consumer perceptions of service quality. Journal of Retailing, 64(1), $12-40$.

Purnomo, S., Rahayu, E. S., Riani, A. L., Suminah, S., \& Udin, U. (2020). Empowerment model for sustainable tourism village in an emerging country. Journal of Asian Finance, Economics and Business, 7(2), 261-270. https://doi.org/10.13106/jafeb.2020. vol7.no2.261

Ramsaran-Fowdar, R. R. (2007). Developing a service quality questionnaire for the hotel industry in Mauritius. Journal of Vacation Marketing, 13(1), 19-27.

Rojas, C., \& Camarero, C. (2008). Visitors' experience, mood and satisfaction in a heritage context: Evidence from an interpretation center. Tourism Management, 29(3), 525-537.

Sanchez-Garcia, I., \& Curras-Perez, R. (2011). Effects of dissatisfaction in tourist services: The role of anger and regret. Tourism Management, 32(6), 1397-1406. 
Sparks, B., \& Browning, V. (2010). Complaining in cyberspace: The motives and forms of hotel guests' complaints online. Journal of Hospitality Marketing \& Management, 19(7), 797-818.

Su, Y., \& Teng, W. (2018). Contemplating museums' service failure: Extracting the service quality dimensions of museums from negative on-line reviews. Tourism Management, 69, 214-222.

Sumantri, Y. (2019). Lean Adoption in Third Party Logistics Industry to Achieve Efficient Logistics Activities. Journal of Distribution Science, 17(12), 71-79. https://doi.org/http:// dx.doi.org/10.15722/jds.17.12.201912.71

Sumantri, Y. (2020). Drivers of logistics service innovation in Third Party Logistics business. IOP Conference Series:
Materials Science and Engineering, 732, 012068. https://doi. org/10.1088/1757-899X/732/1/012068

Theobald, M. M. (2000). Museum store management. Walnut Creek, CA: Alta Mira Press.

Titu, M. A., Raulea, A. S., \& Titu, S. (2016). Measuring service quality in tourism industry. Procedia - Social and Behavioral Sciences, 221(June), 294-301.

Tzortzi, K. (2016). Museum space. New York, NY: Routledge.

Weerawardena, J., \& Mort, G. S. (2006). Investigating social entrepreneurship: a multidimensional model. Journal of World Business, 41(1), 21-35.

Weil, S. (2002). Making museums matter. Washington DC: Smithsonian Institution Press. 